\title{
Mussel production as a nutrient mitigation tool for improving marine water quality
}

\author{
Karen Timmermann ${ }^{1, *}$, Marie Maar ${ }^{1}$, Karsten Bolding ${ }^{2}$, Janus Larsen' ${ }^{1}$, \\ Jørgen Windolf ${ }^{3}$, Pernille Nielsen ${ }^{4}$, Jens Kjerulf Petersen ${ }^{4}$

\begin{abstract}
${ }^{1}$ Marine Ecology and Modelling, Department of Bioscience, Aarhus University, 4000 Roskilde, Denmark
${ }^{2}$ Bolding \& Bruggeman ApS, Strandgyden 25, 5466 Asperup, Denmark

${ }^{3}$ Catchment Science and Environmental Management, Department of Bioscience, Aarhus University, 8600 Silkeborg, Denmark
\end{abstract} \\ ${ }^{4}$ Danish Shellfish Centre, DTU Aqua, 7900 Nykøbing Mors, Denmark
}

\begin{abstract}
Longline mussel farming has been proposed as a tool to remove nutrients and counteract the negative effects of eutrophication in coastal waters. In this study, we use coupled 3D hydrodynamic and ecological modelling in combination with measurements from a full-scale mitigation farm to assess the environmental effects of mitigation cultures in Skive Fjord, Denmark, a shallow eutrophic estuary. The results show that mitigation cultures decrease chl a concentration and increase Secchi depth especially in the surroundings of the farms but also on a basin scale. Fecal production by the mussels increases sedimentation below the farms but reduces ambient sedimentation, resulting in a net decrease in sedimentation of organic material on a basin scale. Comparisons with nutrient load reduction scenarios indicate that nutrient removal by mitigation cultures have a higher short-term impact on water quality parameters (chl $a$, Secchi depth and sedimentation) than nutrient removal using land-based measures.
\end{abstract}

KEY WORDS: Eutrophication - Mussel culture - Nutrients · Modelling - DEB model · Water quality indicators

\section{INTRODUCTION}

Eutrophication of coastal waters is one of the major environmental challenges worldwide resulting in e.g. turbid water outshading benthic vegetation, algal blooms and hypoxia (Anderson et al. 2002, Nielsen et al. 2002, Carstensen et al. 2007, Diaz \& Rosenberg 2008, Anton et al. 2011). Excess nutrients, mainly from land, have long been identified as the key driver of eutrophication-related problems (Carpenter et al. 1998); consequently, systematic nutrient load reductions of both phosphorus and nitrogen from land have been the keystone in coastal ecosystem management for decades. Different approaches have been applied to reduce nutrient export from the land to the sea. Wastewater treatment plants have been upgraded to address point sources, but it has

${ }^{*}$ Corresponding author: kt@bios.au.dk been more challenging to reduce the diffuse runoff of nutrients from land, mainly coming from agriculture. A variety of land-based mitigation measures such as mandatory fertilizer plans, improved utilization of manure and reestablishment of wetlands have been implemented (Kronvang et al. 2008). The result has so far been that, in Denmark, nitrogen and phosphorus load has been reduced by 40 and $60 \%$, respectively, over the last 3 decades (Maar et al. 2016). In recent years, the first signs of ecosystem recovery have emerged (Riemann et al. 2016). However, even when land-based load reductions are implemented, it might take decades before significant improvements are observed, and in many areas, land-based mitigation might not be sufficient to ensure good water quality as required by, for example, the EU Water Framework Directive (WFD). Furthermore,

(C) The authors 2019. Open Access under Creative Commons by Attribution Licence. Use, distribution and reproduction are unrestricted. Authors and original publication must be credited. 
land-based mitigation measures are not capable of addressing the internal load from sediments resulting from the historic accumulation of sedimented organic material, which can be significant and may even exceed loading from land especially during summer (Christensen et al. 1994, Jørgensen et al. 1996). In recent years, focus has turned to alternative mitigation measures including marine mitigation measures that can be applied within the marine recipients. Mussel farming has been proposed as a marine mitigation measure to remove excess nutrients from marine coastal waters (Petersen et al. 2014). The basic principle of mitigation mussel farming is that the mussels remove nutrients contained in particles (mainly phytoplankton) directly from the water through their feeding activity and incorporate them into animal tissue during growth. When the mussels are harvested, nutrients are removed from the marine environment and brought back to land. Mussels produced at farms optimized for nutrient mitigation purposes are aimed at maximizing total biomass rather than individual mussel size and appearance. This production method maximizes nutrient removal but makes the mussels less suited for human consumption due to uneven and often very small size (Petersen et al. 2016). Mitigation mussels can, however, be valuable protein-rich feed for husbandry (Nørgaard et al. 2015, Afrose et al. 2016). In Danish waters, blue mussel Mytilus edulis is an obvious choice for mitigation purposes, and recent results from the first full-scale blue mussel farm optimized for mitigation purposes have proven it possible to remove significant amounts of both nitrogen and phosphorus at costs comparable to most land-based mitigation measures (Petersen et al. 2014). The nutrient removal capacity by mitigation cultures is controlled by mussel growth rate, and in many marine environments, food limitation is the key factor controlling bivalve growth in shellfish farms (Strohmeier et al. 2005). However, in most eutrophic coastal environments, the food supply is sufficient to support fast-growing mussel populations as long as the carrying capacity is not exceeded (Nielsen et al. 2016).

Besides the nutrient removal effects caused by incorporation of organically bound nutrients into mussel tissue and subsequent mussel harvest, mitigation mussel culturing also has additional effects on marine water quality. Mussel filtration reduces seston concentration, resulting in lower chlorophyll a (chl a) concentration and increased water transparency (Schröder et al. 2014). These effects are most pronounced in the local environment around the farm, but since phytoplankton production within a farm is insufficient to support mussel growth, a larger area will be affected by the filter activity. It has been documented that dense populations of clams can shift an estuary from a turbid bottom-up controlled state to a top-down controlled clear water state solely driven by clam filtration (Petersen et al. 2008). Based on documented system-wide effects of shellfish filtration and the observations of seston reduction and even depletion at the farm scale, it is hypothesized that several mussel mitigation farms would display seston reduction and subsequent increased water transparency at the basin scale.

Nutrient regeneration within a mussel farm is relatively high (Cranford et al. 2007, Holmer et al. 2015), and the released nutrients can be used to support new primary production. The increased sedimentation of fecal material and pseudo-feces underneath a mussel farm has impact on the benthic biogeochemical cycles and may increase the local sediment oxygen demand, as shown in several studies (Christensen et al. 2003, Giles et al. 2006, Carlsson et al. 2009). It has been documented that the accumulation of organic material in sediment underneath mussel farms often results in a local increase in benthic nutrient fluxes. This effect may stimulate primary production and to some extent counteract the mitigation effects of the mussels. In addition, denitrification rates may also be affected by the increased local sedimentation. Depending on the local sedimentation rates and oxygen and sulphide concentrations, denitrification is either stimulated or inhibited (Christensen et al. 2000, Carlsson et al. 2012). The increase in local sedimentation resulting from fecal production may, however, be counterbalanced by decreased sedimentation on a basin scale resulting from the filter activity and accumulation of organic material.

Whereas direct nutrient removal is easy to assess by measurements of the harvested biomass, the effects on water quality indicators such as chl $a$ and light transparency on a basin scale are less evident, and the complex interactions between mussels and the ambient environment make it difficult to predict the environmental impact of mitigation cultures. The objective of this study is to examine if and to what extent mitigation cultures can be used to improve marine water quality and evaluate the environmental effects of mitigation cultures on a basin scale. The hypothesis is that blue mussel filtration reduces chl a concentration and sedimentation and improves light transparency on a basin scale. Second, we expect that nutrient removal using mitigation mussels reduces phytoplankton concentration more efficiently compared to nutrient load reduction from land because 
mussels directly filter the water, whereas nutrient load reductions only indirectly affect chl a concentration by limiting primary production. To test the hypothesis, we developed a model complex consisting of a 3D hydrodynamic-biogeochemical model coupled with a dynamic energy budget (DEB) model for blue mussels. The model complex was parameterized and calibrated using monitoring data and measurements from an experimental full-scale mitigation culture in Skive Fjord, Denmark (Petersen et al. 2014).

\section{MATERIALS AND METHODS}

\subsection{Study site}

The Skive Fjord estuarine complex is an inner branch of Limfjorden, which is a shallow sound connected to the North Sea on the west coast (32-34 psu) and to the Kattegat (19-25 psu) on the east coast (Fig. 1). The Skive Fjord complex consists of the 2 basins Skive Fjord and Lovns Bredning as well as Hjarbæk Fjord located in the south of the estuarine complex and separated from Lovns Bredning by a sluice. A full-scale longline mussel farm located in the northern part of Skive Fjord was used as the experimental study site to test the environmental

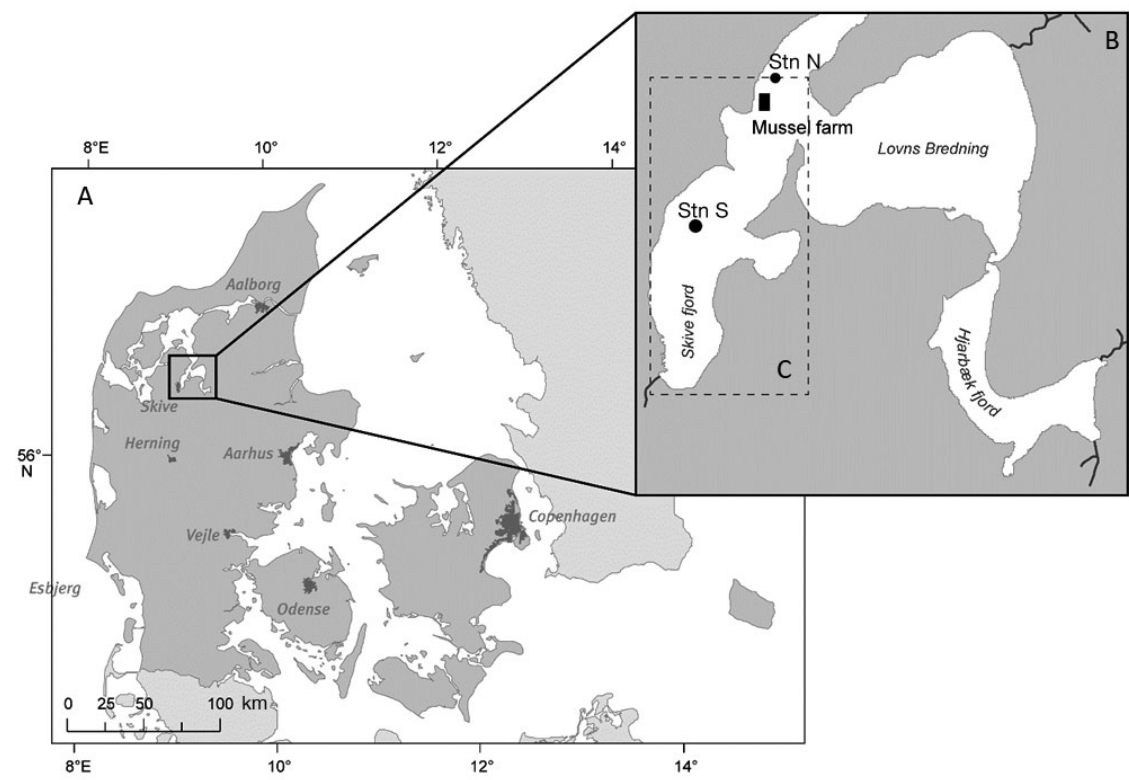

Fig. 1. (A) Location of the Skive Fjord complex, Denmark, with (B) a close-up of the model domain covering Skive Fjord, Lovns Bredning and Hjarbæk Fjord. The mitigation mussel culture unit optimized for nutrient removal is located in the northern part of Skive Fjord ( $\square$ ). The monitoring station providing data for boundary conditions, Stn $N(\bullet)$, is located north of the farm, whereas the monitoring station used for model validation, $\operatorname{Stn} \mathrm{S}(\bullet)$, is located south of the mussel farm. In the present study, basin scale is defined as (C) Skive Fjord, whereas local scale is related to a single mussel farm impact of mitigation mussels on a farm scale and to provide data for model validation. The estuarine complex has a surface area of approximately $250 \mathrm{~km}^{2}$ and a mean water depth of $4.6 \mathrm{~m}$. It is a partially mixed system, with stratification occurring on a scale from days to weeks, depending on the freshwater input, radiation and wind mixing (Mohlenberg 1999). The entire estuarine complex is characterized as eutrophic with high $\left(>10 \mu \mathrm{g} \mathrm{l}^{-1}\right)$ chl a concentrations throughout the growth period and with seasonal hypoxia occurring in the late summer (Maar et al. 2010). The catchment area is $2621 \mathrm{~km}^{2}$, of which $67 \%$ is intensively farmed with a livestock density of 1.38 livestock ha ${ }^{-1}$. There is a fishery of blue mussels Mytilus edulis (approx. 2000-5000 t $\mathrm{yr}^{-1}$ in recent time), whereas there are only a few commercial mussel farms (harvest $<1300 \mathrm{t} \mathrm{yr}^{-1}$ ).

\subsection{Monitoring and field campaigns}

Measurements of chl $a$, nutrients $\left(\mathrm{NO}_{3}{ }^{-}, \mathrm{NH}_{4}{ }^{+}\right.$, $\mathrm{PO}_{4}{ }^{3-}$ ) and Secchi depth were monitored every second week from June 2010 to May 2011 at 5 different locations inside and outside the farm to detect potential effects of the mussel farm and to provide boundary and validation data for the model. The estuary was covered with ice from December to March, and during this period, sampling was only possible on 2 occasions and only took place inside the farm. Water samples were taken at the monitoring stations in surface $(1 \mathrm{~m})$ and bottom (1 $\mathrm{m}$ above the sediment surface) waters. Fluorescence was measured in connection with CTD casts using a calibrated CTD sensor and an integrated chl a fluorescence sensor (ECO-probe, Meerestechnik Elektronik). Water samples were collected with a 1.71 Niskin sampler. Three subsamples were filtered onsite through Whatman glass fiber filters, and water samples were kept dark and cold during transport to the laboratory. The filtered water was stored frozen until analysis of nutrients $\left(\mathrm{NH}_{4}{ }^{+}, \mathrm{NO}_{3}{ }^{-}, \mathrm{PO}_{4}{ }^{3-}\right)$ by use of a Lachat nutrient analyzer.

Mussel ropes were sampled on 7 random occasions from July 2010 to June 2011 to determine growth of 
individual mussels and estimate total mussel biomass in the farm. On each sampling occasion, 30 samples of $1 \mathrm{~m}$ mussel rope were collected from the same lines in the farm. The 30 mussel rope samples were then brought to the laboratory, where the length of individual mussels was measured as well as wet and dry weights of tissue, shells and byssus. For additional information on the mussel farm and sampling in and around it during the period June 2010 to May 2011, see Petersen et al. (2014), Holmer et al. (2015) and Nielsen et al. (2016).

In addition, nutrient and chl a data measured as part of the Danish National Aquatic Monitoring and Assessment Program from monitoring stations in Skive Fjord (Stn S, Fig. 1) were used for validation. Water sampling and chemical analysis were carried out according to official technical guidelines (http://bios. au.dk/videnudveksling/fagdatacentre/fdcmarintny/ gaeldendetekniskeanvisninger/\#c236812).

\subsection{Coupled 3D hydrodynamic-ecological model}

The model simulations were carried out using a model framework comprising a 3D hydrodynamic model, the General Estuarine Transport Model (GETM) (Burchard et al. 2004, Hofmeister et al. 2009), coupled to a biogeochemical model (DANECO) (Maar et al. 2009, Timmermann et al. 2010) and further including a DEB model (Maar et al. 2010), simulating growth of blue mussels. The coupling between the GETM, DANECO and DEB models is done using the Framework for Aquatic Biogeochemical Models (Bruggeman \& Bolding 2014). GETM is a 3D primitive equation model with full thermodynamics, and the hydrodynamic model setup for Limfjorden and Skive Fjord-Lovns Bredning is described in Hofmeister et al. (2009), including performance tests and results. In the specific model setup, a Cartesian grid with an equidistant grid size of $200 \mathrm{~m}$ is applied. In the vertical, zoomed sigma coordinates are used with 10 layers. The area of Skive FjordLovns Bredning is shown in Fig. 1. This is only a subpart of Limfjorden and is used for the fully coupled simulations. Boundary conditions for physical variables are provided through a 1-way nesting from a physics-only model setup for the entire Limfjorden. Four sources of freshwater and riverine inputs were included in the model setup for Skive Fjord, Hjarbæk Fjord and Lovns Bredning, reflecting the location of the largest streams in the Skive Fjord complex.

The applied ecological model (DANECO) is based on the microplankton-detritus model originally devel- oped by Tett (1998) for the North Sea and modified to provide a more adequate description of the benthic and pelagic processes in the Danish estuaries (Maar et al. 2009, Timmermann et al. 2010). The DANECO model describes benthic and pelagic biogeochemical cycles of carbon, nitrogen and phosphorus through microplankton (auto- and heterotrophs) and detrital compartments with the associated changes in dissolved concentrations of $\mathrm{NO}_{3}{ }^{-}, \mathrm{NH}_{4}{ }^{+}, \mathrm{PO}_{4}{ }^{3-}$ and $\mathrm{O}_{2}$ (Fig. 2). Chl a concentrations are derived from the internal $\mathrm{N}$ content of phytoplankton cells using a conversion factor of $2.0 \mathrm{mg}$ chl a per mmol N. Separate state variables for $\mathrm{C}, \mathrm{N}$ and $\mathrm{P}$ in cells and detritus are applied allowing for varying $\mathrm{C}: \mathrm{N}$ ratios in organic particles (microplankton and detritus). Sedimenting detritus and microplankton enter the benthic layer, where they are gradually respired and remineralized by bacteria using the same functions as for detritus in the water column. Dissolved inorganic nutrients are transferred between the sediment pore water and pelagic compartment by diffusive fluxes.

\subsection{Mussel farm model}

Mitigation mussel cultures are simulated by allowing mussel growth in the water column in 3 horizontal model grid cells roughly corresponding to the size of the 3 farm sections (each $250 \times 200 \mathrm{~m}$, with the locations north, middle and south) and from 1 to $5 \mathrm{~m}$ below the surface. A DEB model for blue mussels calibrated to Skive Fjord (Maar et al. 2010) was used to calculate mussel growth expressed as dry weight (g) and shell length (cm). The DEB model describes the energy flow through an organism from ingestion and assimilation of food to the allocation from reserves to growth, maintenance and reproduction in response to temperature and food (Fig. 2). The DEB theory was originally developed by Kooijman (1986) and has since been successfully applied to different bivalves (Van Haren \& Kooijman 1993, Pouvreau et al. 2006, Kooijman 2010). The present version describes $\mathrm{C}, \mathrm{N}$ and $\mathrm{P}$ dynamics of the DEB state variables, which depend on the $\mathrm{C}: \mathrm{N}: \mathrm{P}$ ratio of the ingested food. The DEB model is combined with a cohort model describing abundance and loss of individuals within a single cohort. Self-thinning on the longlines is assumed to be the only loss (apart from harvest) based on observations (Nielsen et al. 2016). The most important mussel predators in the Limfjorden are shore crabs Carcinus maenas and starfish Asterias rubens, but they did not enter the longlines, and there are no important bird predators in the area. 

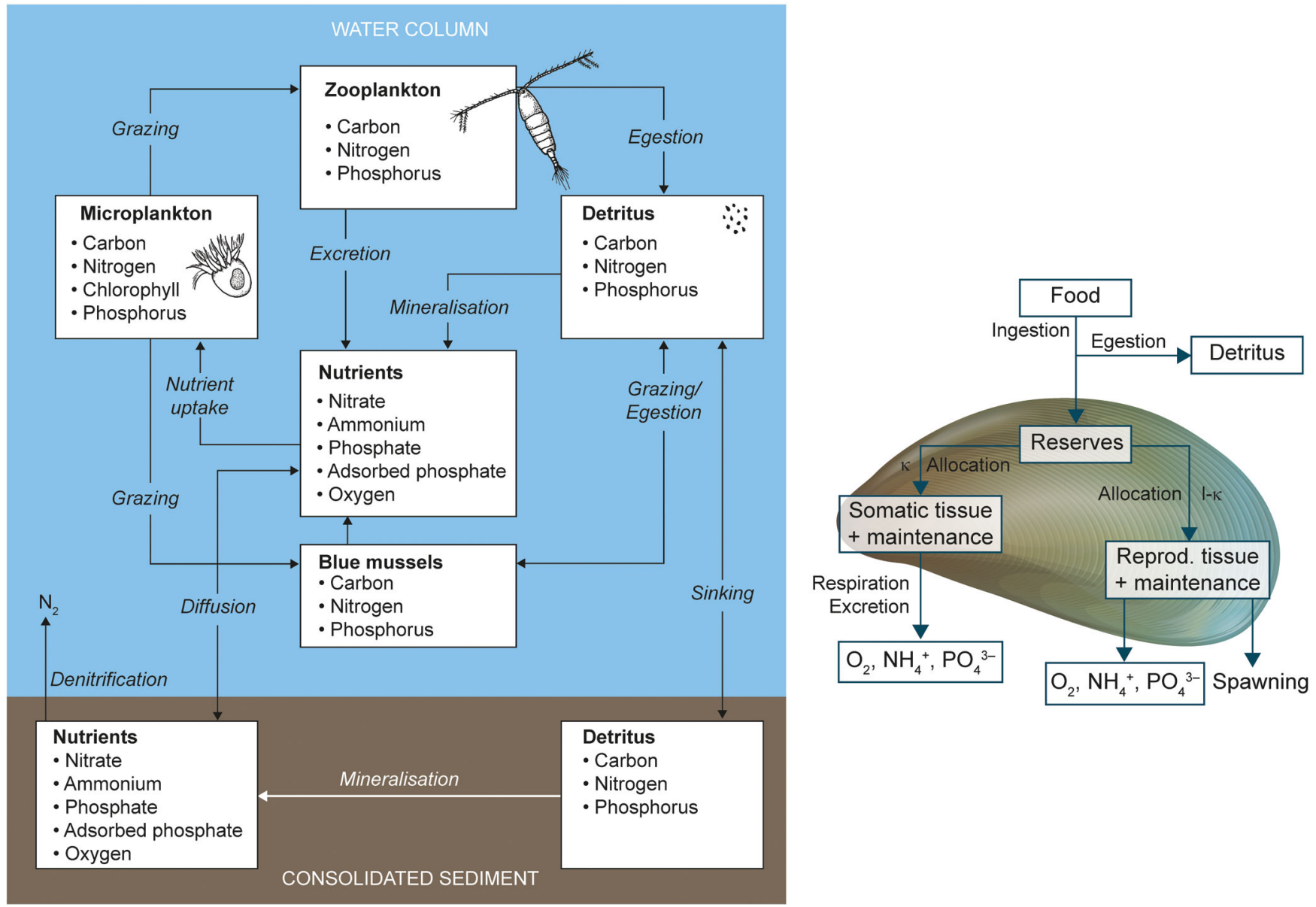

Fig. 2. Conceptual diagram of the coupled ecological DANECO model (left) and dynamic energy budget (DEB) model (right) for blue mussels used to assess and predict environmental effects of mitigation cultures. For both models, boxes represent state variables, whereas arrows represent processes. The feedback processes between DANECO and the DEB model are mussel ingestion of food (microplankton and detritus carbon, nitrogen and phosphorus), nutrient excretion, respiration and egestion of fecal pellets into the DANECO detritus pool

\subsection{Coupling of the DEB and DANECO models}

The DEB model is coupled to the DANECO model by a 2-way coupling, allowing for feedback processes between the mussels and the environment (Maar et al. 2010). The feedback processes include ingestion of microplankton and detritus by the mussels, resulting in removal of organic N, P and C from the ecological model and an increase of $\mathrm{C}, \mathrm{N}$ and $\mathrm{P}$ in the DEB model. The coupling processes also include respiration and nutrient excretion by the mussels, resulting in a decrease of (inorganic) nutrients in the DEB model and a subsequent increase in inorganic nutrients $\left(\mathrm{NH}_{4}{ }^{+}\right.$and $\left.\mathrm{PO}_{4}{ }^{3-}\right)$ and decrease of oxygen in the ecological model. The egestion of fecal pellets by mussels also constitutes a coupling process where the amount of (organic) N, P and C in the DEB model decreases and enters the ecological model as detri- tus, which can be degraded, advected and sedimented. Besides the coupling processes, which directly transport nutrients and carbon between the DEB model and the ecological model, the process rates within the DEB model also depend on the salinity, oxygen and temperature state variables in the ecological model (Maar et al. 2010). The prevailing salinity conditions were assumed not to affect filtration or growth.

\subsection{Hindcast scenario}

The coupled 3D model with the implemented mussel farm unit is used to simulate the hydrodynamic and ecological conditions in the Skive Fjord estuarine complex from June 2010 to May 2011. This time period corresponds to the field experimental period 
for the full-scale mitigation mussel farm covering settling of the mussel larvae and harvest. In Skive Fjord and most inner Danish waters, cultured mussel biomass reaches a maximum within 1 yr. Thus, growing mitigation cultures for longer time periods is neither environmentally beneficial (nitrogen removal) nor cost effective (Petersen et al. 2019). Meteorological forcing (10 m wind, $2 \mathrm{~m}$ temperature, cloud cover, surface pressure and humidity) is obtained from an operational weather forecast model (http://weprog. org) with an hourly resolution. Open boundary conditions for the hydrodynamic variables are provided through a 1-way nesting from a physics-only model setup for the entire Limfjorden (Hofmeister et al. 2009).

Open boundary conditions for the ecological state variables (nutrients, oxygen and chl a) were based on depth- and time-interpolated monitoring data from the monitoring station located north of the farm (Stn N, Fig. 1).

Daily means of freshwater discharges and riverine inputs of total nitrogen (TN) and total phosphorus (TP) to the Skive Fjord marine complex were estimated based on measurements in streams from the monitored part of the catchment (Andersen et al. 2005, Kronvang et al. 2008) covering approximately $60 \%$ of the area as well as on modelled water and nutrient inputs from the ungauged part of the catchment using the national DK-QNP model (Windolf et al. 2011) with bias correction (Windolf et al. 2013). Nutrients from point sources (wastewater treatment plants) were calculated based on available data from the Danish Environmental Agency.

Riverine inputs of TN and TP were distributed into the relevant nutrient pools using the distribution pattern measured in Horsens estuary in 2001 (Markager et al. 2011). For TN, the applied distribution pattern was 0.2:0.61:0.19 for $\mathrm{NH}_{4}{ }^{+}, \mathrm{NO}_{3}{ }^{-}$and detritus $\mathrm{N}$, respectively. For $\mathrm{TP}$, the applied distribution pattern was 0.12:0.71:0.17 for $\mathrm{PO}_{4}{ }^{3-}$, adsorbed $\mathrm{P}$ and detritus $\mathrm{P}$, respectively.

Model results from the hindcast simulation were compared with measurements of temperature, salinity, oxygen, $\mathrm{NH}_{4}{ }^{+}, \mathrm{NO}_{3}{ }^{-}, \mathrm{PO}_{4}{ }^{3-}$ and chl a from the national marine monitoring station in Skive Fjord (Fig. 1).

\subsection{Scenarios}

The impact of the mussel farm was assessed by running the hindcast scenario without the mussel farm but otherwise using the same forcing and simulation period. Results were computed as the relative difference between scenarios with and without the mussel farm.

The impact of introducing several mitigation mussel units in Skive Fjord was tested by implementing 1 to 10 additional model farms at suitable locations characterized by having sufficient depth $(>5 \mathrm{~m})$ to avoid the longlines reaching the sea floor. The area of the individual farms varied from 12 to $24 \mathrm{ha}$, with different line lengths, depending on the water depth. The total farm volume in the scenarios varied from 36 $\times 10^{4}$ to $80 \times 10^{4} \mathrm{~m}^{3}$. Model farms were placed at sufficient distances to avoid mutual interactions influencing mussel growth.

Nutrient load reduction scenarios were performed by decreasing TN concentrations in the local freshwater sources to Skive Fjord by 10, 30 and $50 \%$ of the concentrations used in the hindcast simulation, corresponding to a load reduction of approximately 2 , 6 and $10 \%$ of the total riverine nitrogen loading to the water body covered by the model (Fig. 1B). The local Skive Fjord freshwater sources originate from a catchment area of $915 \mathrm{~km}^{2}$, accounting for $35 \%$ of the total catchment and approximately $20 \%$ of total riverine nitrogen input.

Scenario results are presented as the relative difference between the hindcast simulation and the scenario. For chl $a$, the relative difference in summer (June-September 2010) averages is used, whereas for Secchi depth and sedimentation, the relative difference in yearly (June 2010-May 2011) averages is used.

Nutrient removal (in $\mathrm{t} \mathrm{N} \mathrm{yr}^{-1}$ ) either by mitigation cultures or by nutrient load reductions is calculated on a yearly basis for comparison based on the expected harvest (after $1 \mathrm{yr}$ ) or accumulated (JuneMay) reduced loading.

\section{RESULTS}

\subsection{Model validation}

Surface water temperatures in the simulation period ranged from $21^{\circ} \mathrm{C}$ in July-August to $-0.6^{\circ} \mathrm{C}$ in January-February. During winter (DecemberMarch), the water surface in the farm was covered with a $0.5 \mathrm{~m}$ thick layer of ice. Mean salinity in Skive Fjord and Lovns Bredning was 24.5 and 23.2 psu, respectively, but with temporal variations between 16 and 28 psu.

The coupled hydrodynamic and ecological model captured the seasonal trends in $\mathrm{NO}_{3}$ and $\mathrm{PO}_{4}{ }^{3-}$ (Fig. 3), including the high summer and autumn 

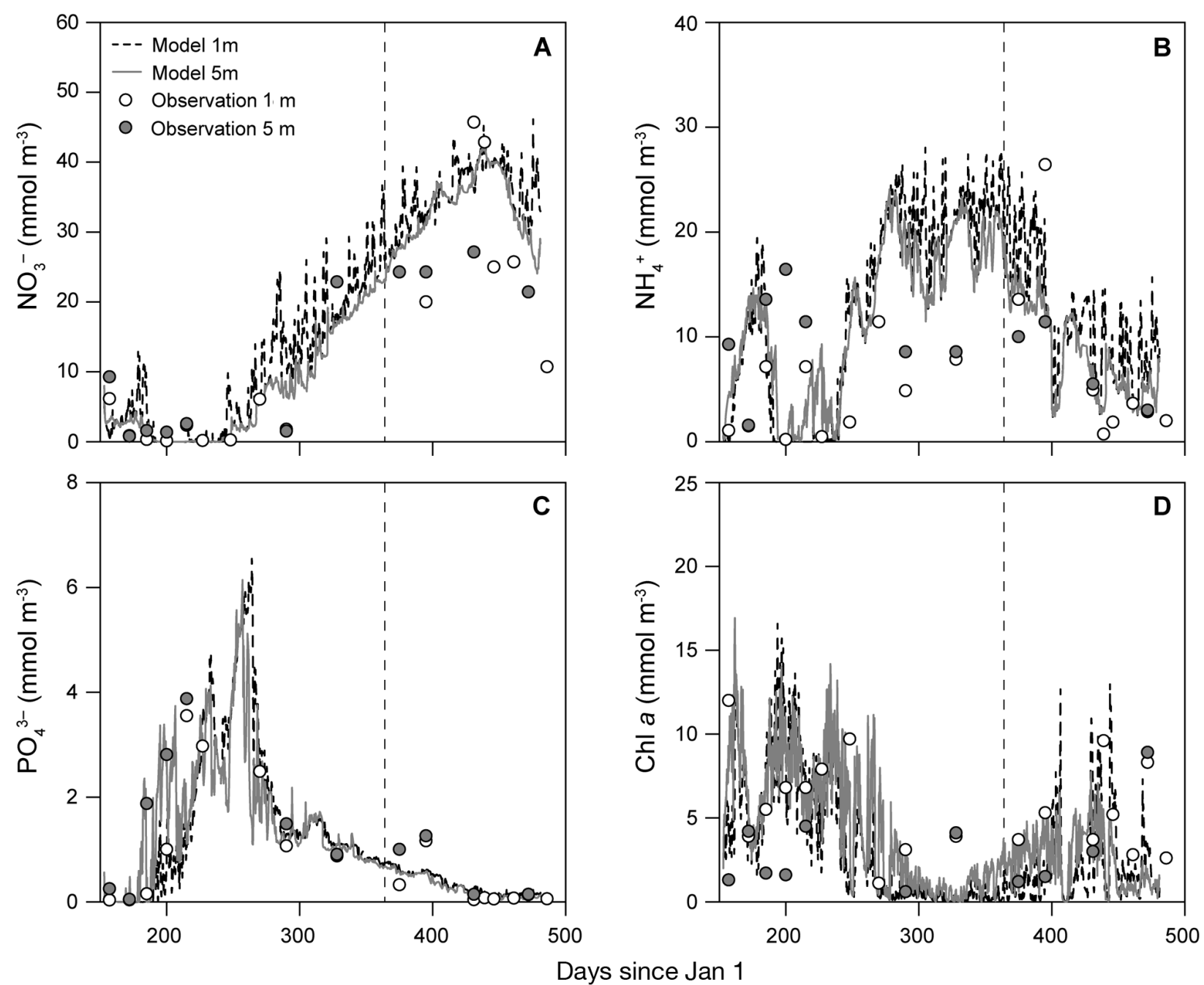

Fig. 3. Measured (circle) and modelled (line) surface (1 m) and bottom (5 m) water concentrations of (A) nitrate, (B) ammonia, (C) phosphate and (D) chl a

concentrations of phosphate resulting from hypoxiainduced nutrient release from the sediments. The seasonal pattern of nitrate followed a classical pattern with high winter concentrations and depletion during the phytoplankton growth season, and this pattern was captured by the model, as indicated by a high correlation between measured and model-simulated concentrations of nitrate $\left(\mathrm{R}^{2}=0.79\right)$. The seasonal pattern of both phosphate and ammonium concentrations was influenced by nutrient release from the sediment during summer with frequent occasions of hypoxia and anoxia resulting in high nutrient concentrations in the later part of the growth season. There was a generally good agreement between measured and modelled concentrations of phosphate $\left(R^{2}=0.69\right)$, whereas the model tended to overestimate the ammonium concentration in the late autumn $\left(\mathrm{R}^{2}=0.30\right)$.
As a consequence of the nutrient release from the sediment, phytoplankton biomass was characterized by a high autumn chl a concentration exceeding the spring bloom. This seasonal chl a pattern, which is characteristic of a highly eutrophic estuary influenced by anoxia, was also captured by the model $\left(\mathrm{R}^{2}=0.55\right)$.

Shell length and biomass of individual mussels increased from June until November 2010, whereafter growth ceased during ice cover in winter (December-March) followed by an increase up to harvest time in May 2011 (Fig. 4). There was a high correlation between simulated shell length $\left(\mathrm{R}^{2}=0.97\right)$ and biomass $\left(\mathrm{R}^{2}=0.88\right)$ of individual blue mussels growing on longlines (average for all farm sections) with observations from the mussel farm (Fig. 4). Modelling results indicated growth differences $(<10 \%$ from the mean) between the sections of the mitigation farm. 


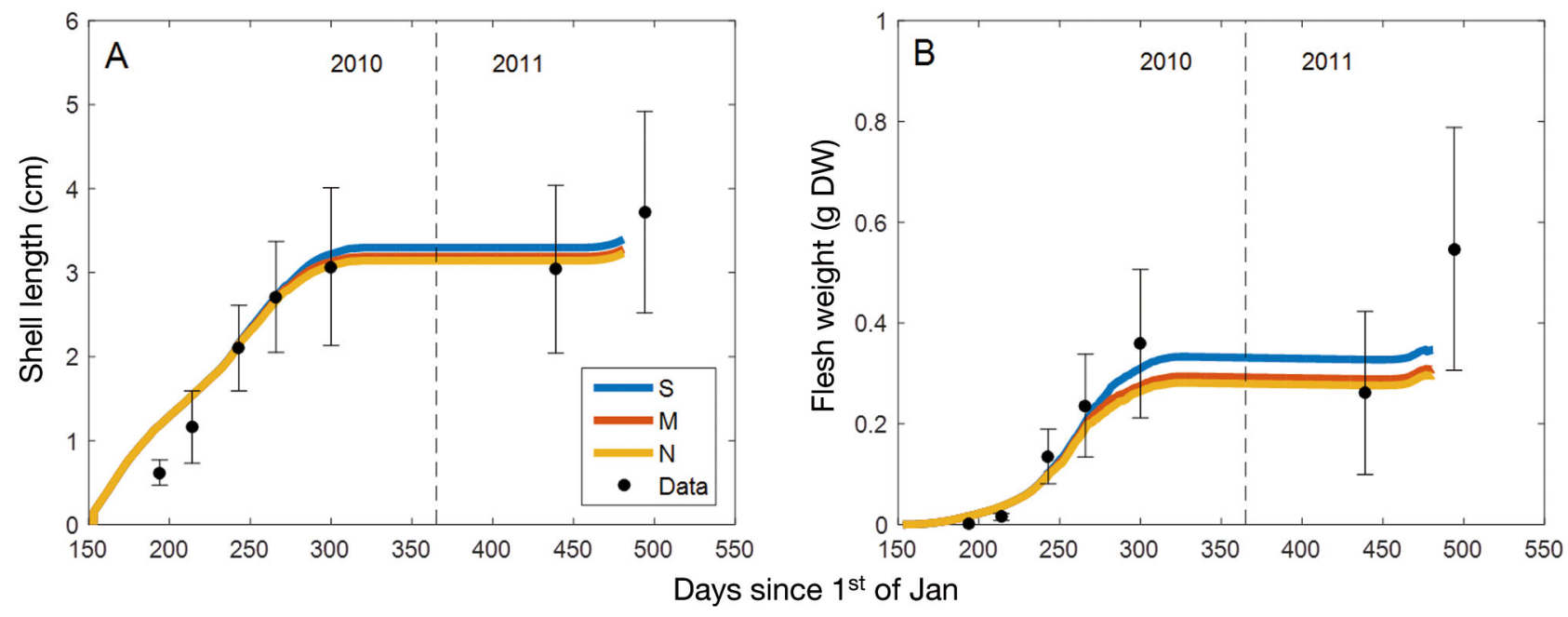

Fig. 4. Measured data and modelled (A) shell length and (B) biomass of individual blue mussels from the southern (S), middle $(\mathrm{M})$ and northern $(\mathrm{N})$ sections of the mussel mitigation culture unit from June 2010 to May 2011. Measured data represent a mixture of mussels from sections $\mathrm{S}, \mathrm{M}$ and $\mathrm{N}$, as no significant difference between sections was detected. Data are mean $\pm \mathrm{SD}$

\subsection{Spatial effects on chl a concentrations and light attenuation}

Water filtration and ingestion of particles by the mitigation culture resulted in decreased summer chl a concentrations and light attenuation (Fig. 5). The effects were most pronounced within the farm, where summer chl a concentration was reduced up to $30 \%$ and light attenuation was reduced up to $14 \%$ compared to a scenario without a mussel farm. The area of impact, however, was not restricted to the farm but extended into ambient waters and even reached the coast (Fig. 5). This result is confirmed by Acrobat towed sensor data showing significant reductions in chl $a$ and suspended particulate matter concentrations within the farm as well as in the ambient water, and the reduction effects seem to reach the coast (Nielsen et al. 2016). Farm size (volume) affected the reduction in chl $a$ and the diffuse attenuation coefficient $\left(K_{\mathrm{d}}\right)$ within the farm as well as the size of the affected area. Also, the number, size and location of farms affect the spatial impact of mussel filtration on chl a concentration and light attenuation (Fig. 5).

\subsection{Spatial effects on sedimentation}

Ingestion of particulate matter and subsequent release of fecal material by the mitigation mussels resulted in an increased sedimentation of organic material below and in the vicinity of culture units (Fig. 6). This increased local biodeposition was, how- ever, counterbalanced by decreased sedimentation outside the unit due to the removal of organic particles from the surrounding waters (Fig. 6). The fecal production increased local sedimentation up to $14 \%$ compared to natural sedimentation rates in Skive Fjord, whereas a reduction in sedimentation rates of up to $6 \%$ was detected outside the farm. Comparable sedimentation measurements in Skive Fjord support the finding that sedimentation within the mussel farm is higher than that outside the farm (Holmer et al. 2015).

\subsection{Basin-scale effects of mitigation cultures}

According to model scenarios, the introduction of additional farms enhanced the positive basin-scale effects of mussel filtration, resulting in an overall decrease in chl a concentration, increased Secchi depth and decreased sedimentation. The environmental effects appeared to be proportional with the total volume of the farms (Fig. 7), with effects of $-1.7 \times 10^{-6} \% \mathrm{~m}^{-3}$ farm for chl $a_{1}-0.6 \times 10^{-6} \% \mathrm{~m}^{-3}$ farm for $K_{\mathrm{d}}$ and $-1.1 \times$ $10^{-6} \% \mathrm{~m}^{-3}$ farm for sedimentation.

The environmental effects of mussel farms were compared with the predicted effects caused by nutrient reductions from land. In this comparison, predicted effects on chl a concentration, $K_{\mathrm{d}}$ and sedimentation were related to the amount of nutrients removed

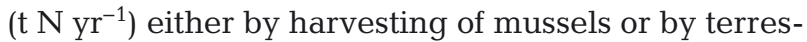
trial measures (Fig. 8). The simulations revealed that the spatially integrated basin-scale environmental effects were more pronounced when mussels were 

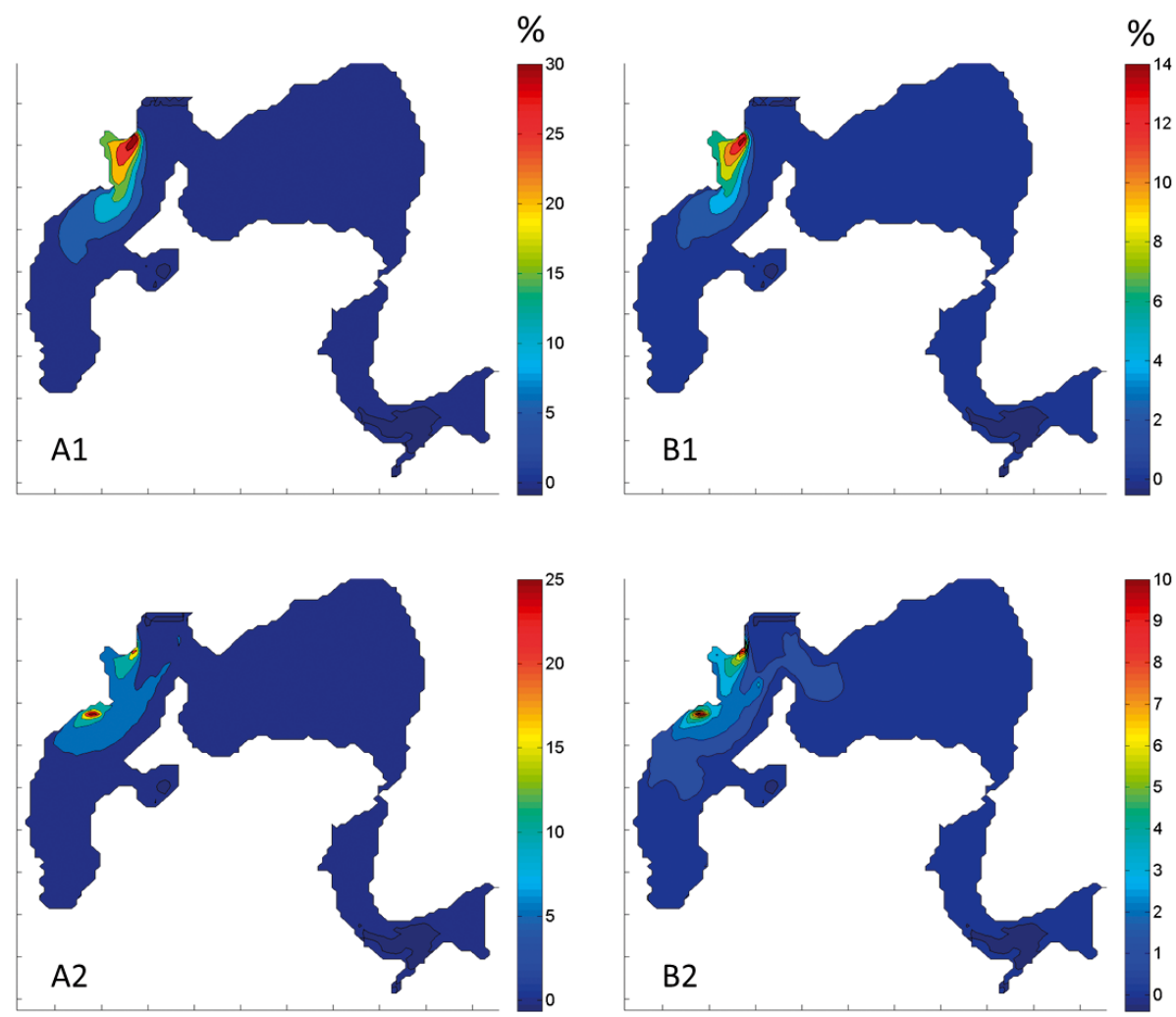

Fig. 5. Modelled spatial effects of mitigation mussel filtration with either 1 large farm (top panels) or 2 smaller farms (bottom panels), resulting in (A) reduction in summer chl a concentration and (B) reduction in light attenuation $\left(K_{\mathrm{d}}\right)$. Results are shown as the nominal relative change (\%) between simulations without and with a mussel mitigation farm. Positive values indicate

that chl $a$ and $K_{\mathrm{d}}$ are reduced in the farm scenario compared to a scenario without mussel mitigation farms

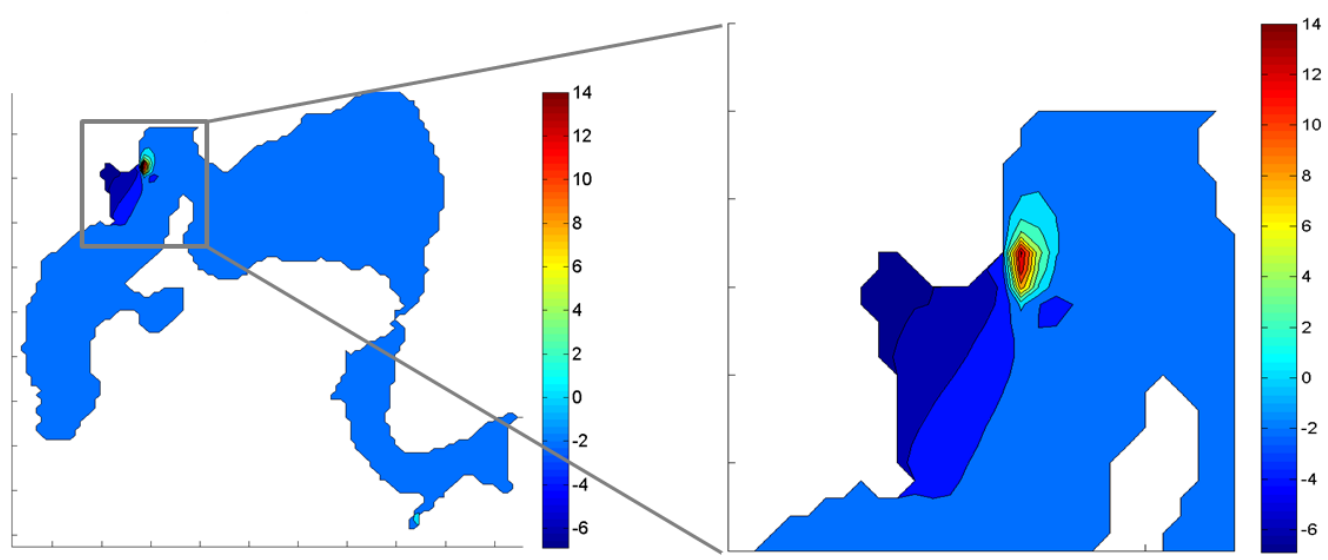

Fig. 6. Modelled spatial effect of mitigation cultures on sedimentation rates. Results are shown as the relative change (\%) between simulations with and without a mussel mitigation farm. Positive values indicate an increased sedimentation compared to a situation without compensation cultures, whereas negative values indicate decreased sedimentation

used to remove (organically bound) nutrients compared to more traditional measures resulting in nutrient load reductions from land (Fig. 8). The relative change in chl a was $37 \times 10^{-3} \%$ per $\mathrm{t}$ of $\mathrm{N}$ removed when nitrogen was removed by mussels, whereas the change was $8 \times 10^{-3} \%$ per $\mathrm{t}$ of $\mathrm{N}$ removed when $\mathrm{N}$ was removed by terrestrial measures. For $K_{\mathrm{d}}$, the changes were $14 \times 10^{-3}$ and $3.7 \times 10^{-3} \%$ per $\mathrm{t}$ of $\mathrm{N}$ removed when nitrogen was removed by mussels and terrestrial measures, respectively. Also, sedimentation was more affected when mussels were used to remove nutrients $\left(24 \times 10^{-3} \%\right.$ per $\mathrm{t}$ of $\mathrm{N}$ removed $)$ 

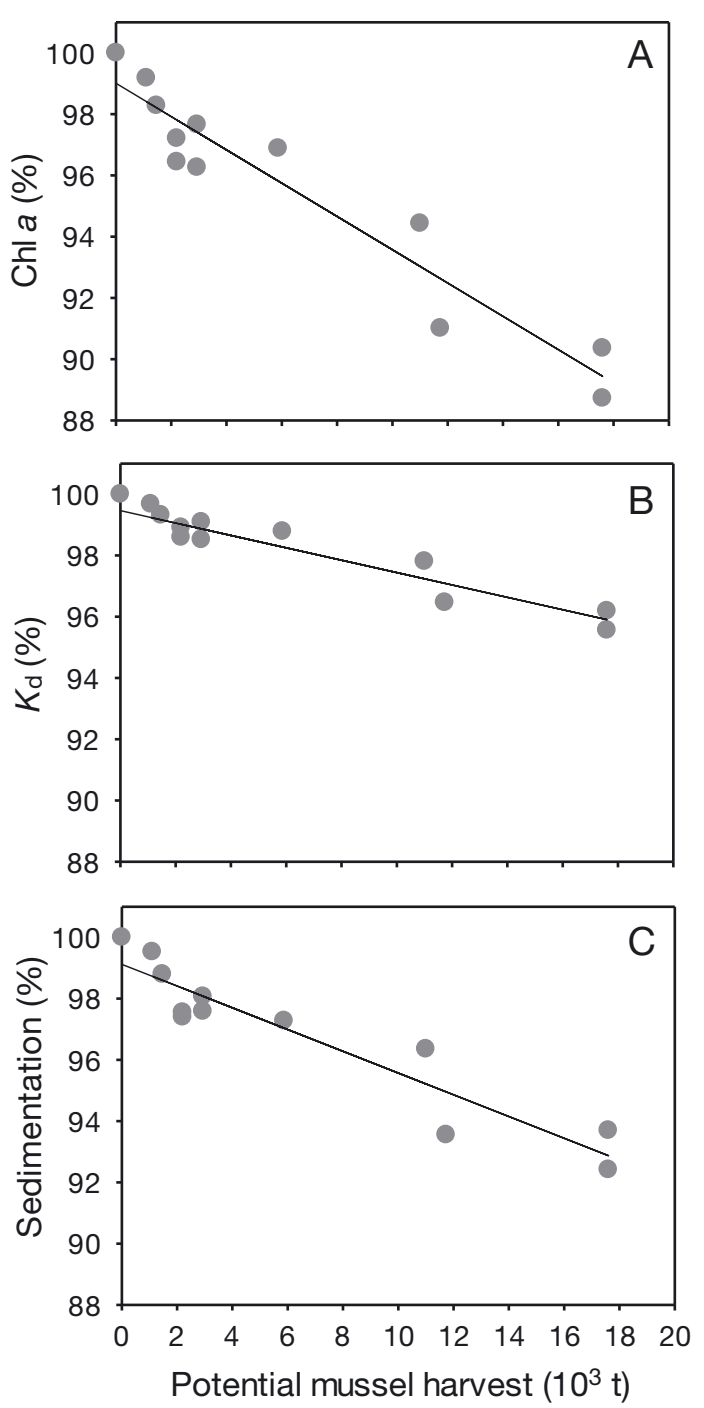

Fig. 7. Spatially integrated basin-scale changes in (A) summer chl a concentration, (B) light attenuation $\left(K_{\mathrm{d}}\right)$ and $(\mathrm{C})$ sedimentation as a function of the total mussel biomass available for harvest in May 2011. Environmental effects of mussel mitigation farms have been integrated over the entire area of Skive Fjord (see Fig. 1C) and are shown as the relative change (in \%) compared to a situation without mussel farms

compared to terrestrial measures $\left(10 \times 10^{-3} \% \mathrm{t}^{-1} \mathrm{~N}\right.$ removed). If the area occupied by the mussel farms was omitted from the spatial integration, basin-scale effects of chl $a$ and $K_{\mathrm{d}}$ reductions were slightly reduced, whereas sedimentation reductions increased (Fig. 8).

\section{DISCUSSION}

Mussel farming has been proposed as a tool to immobilize and remove nutrients and thereby potentially improve water quality (Lindahl et al. 2005, Gal-
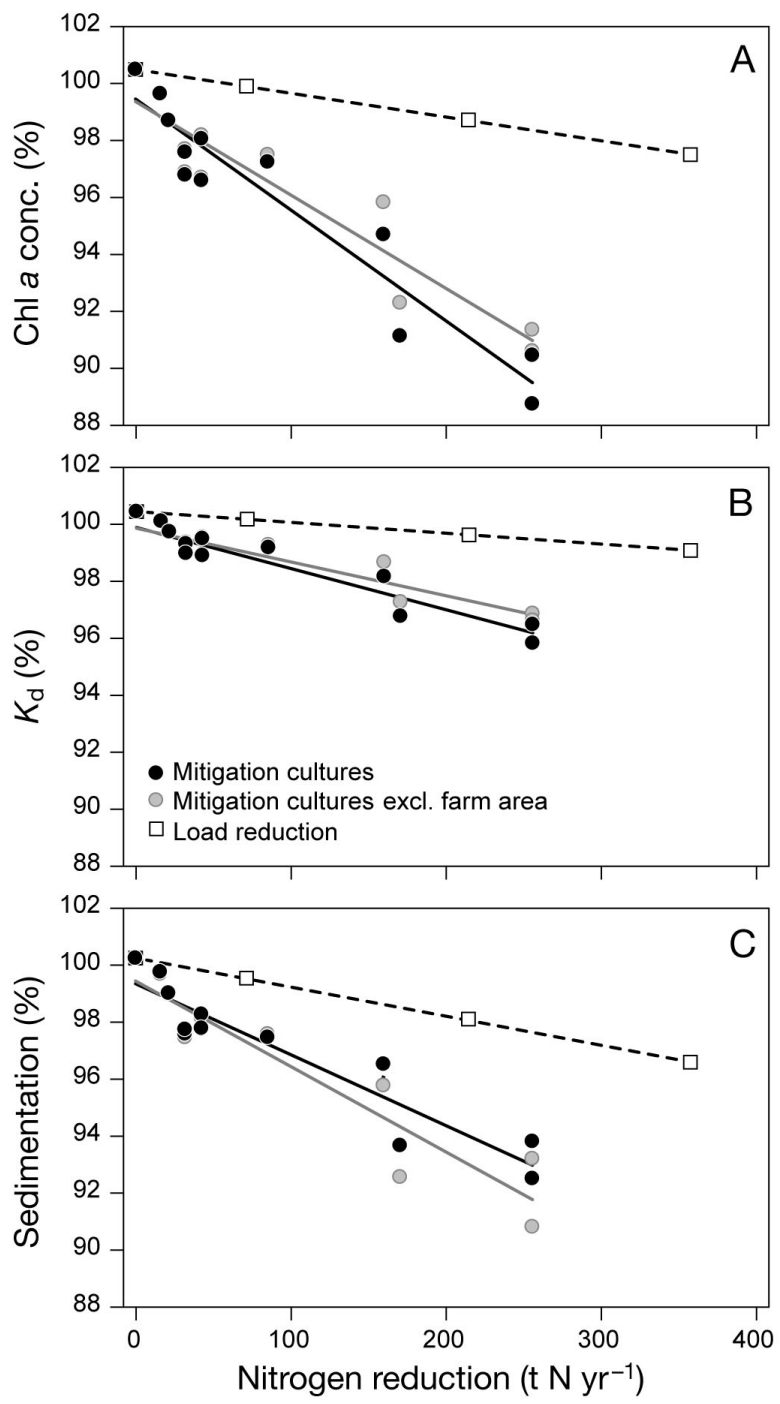

Fig. 8. First-year spatially integrated basin-scale effects on (A) summer chl a concentration, (B) light attenuation $\left(K_{\mathrm{d}}\right)$ and $(\mathrm{C})$ sedimentation as a result of nitrogen reduction either by harvest of mussel mitigation cultures or by nutrient load reductions from land. Nitrogen reduction is calculated after 1 yr (June-May) of either load reductions or mitigation mussel growth and subsequent harvest. Basin-scale effects of nutrient load reduction and mitigation mussel farms have been integrated over the entire area of Skive Fjord (see Fig. $1 \mathrm{C}$ ) either including the area occupied by mussel farms or where effects within the farms have been excluded. All results are shown as relative change between the scenario and a situation with no mussel mitigation farms and no reduction in nutrient loadings

lardi 2014, Petersen et al. 2016). Whereas the cost and area efficiency of using mussels as a tool for nutrient removal has been documented in a few selected areas (Petersen et al. 2014), the environmental effects of mitigation cultures in relation to water quality are less known. Model scenarios from this study revealed that mitigation cultures do have posi- 
tive effects on environmental indicators, not only on a farm scale (Fig. 5) but also on a basin scale (Fig. 7). To obtain good ecological status as required by the WFD, summer chl a concentration has to be improved in Skive Fjord from the current (2007-2012) level of $10.6 \mu \mathrm{g} \mathrm{l}^{-1}$ to the target concentration of $6.0 \mu \mathrm{g}^{-1}$. Also, Secchi depth needs to be improved to support a potential minimum depth distribution of eelgrass Zostera marina of $4.1 \mathrm{~m}$, which is the target for the WFD indicator for eelgrass in Skive Fjord. Although the effects of mussel filtration on environmental indicators (chl $a$ and Secchi depth) were most pronounced within the farm, the area affected by mussel filtration extended to the ambient waters. Mussels are known to be efficient suspension feeders (Riisgård 2001, Petersen et al. 2004), and longline mussels are capable of clearing the water in an area larger than the farm, resulting in increased water transparency (Schröder et al. 2014) and decreased chl a concentration in ambient waters.

According to the model results, the filtration of particles resulted not only in decreased chl a concentrations and improved light conditions (Fig. 7) but also in a redistribution of the organic sedimentation (Fig. 6). As expected, sedimentation was increased underneath the farm due to fecal production, but this local increase in sedimentation was accompanied by a reduced sedimentation outside the mussel farm, resulting in an overall decreased sedimentation on a basin scale (Fig. 7). Increased local sedimentation and accumulation of organic material under production units have been documented in several studies (McKindsey et al. 2011, Carlsson et al. 2012), which has led to concern about hypoxia and anoxia, decreased denitrification and increased nutrient release from the sediment (Stadmark \& Conley 2011). Although the risk of local hypoxia underneath a mussel farm is low (Petersen et al. 2012), studies have shown that denitrification and nutrient release from sediments are often enhanced due to the accumulation of labile organic matter under the farm units (Nizzoli et al. 2006, Carlsson et al. 2012, Humphries et al. 2016). In the eutrophic Skive Fjord, the effects of local increased sedimentation were, however, limited due to the high background concentration of sediment organic matter (Holmer et al. 2015). The intense biodeposition within aquaculture farms has led to conclusions that mussel aquacultures increase the flux of nitrogen to the benthos, with potentially serious eutrophication impacts (Cranford et al. 2007, Testa et al. 2015). The present study indicates that this is only the case on a local scale and not on a basin scale, where sedimentation is decreased. However, mussel aquacultures may increase basin-scale sedimentation in situations where nutrients imported from surrounding water bodies are not flushed out but retained in the sediment due to the presence of mussels and their biodeposition. Since mussel aquaculture does not rely on external nutrient inputs, mussel production and subsequent harvest of mussel biomass will always result in a net removal of nutrients from the aquatic environment.

Despite the local sediment enrichment under the farm, model simulations demonstrated that the mitigation cultures did counteract negative effects of eutrophication by decreasing chl a concentration, improving light conditions and reducing sedimentation on a basin scale. Traditionally, effects of eutrophication are counteracted by reducing nutrient loadings from land through land-based mitigation measures such as reduced fertilization and construction of wetlands. In contrast to land-based measures, marine mitigation measures like mussel cultures are located in the marine recipient far from the typical nutrient sources and do not prevent or counteract pollution at the source. Further, marine mitigation measures do not prevent nutrients from entering the marine ecosystem but may to some extent counteract the negative effects of excess load of nutrients as shown in the present study. In fact, the present results indicate that the short-term environmental effect of removing $1 \mathrm{~kg} \mathrm{yr}^{-1}$ of nitrogen by mussel harvesting is higher than removing $1 \mathrm{~kg} \mathrm{yr}^{-1}$ by landbased measures (Fig. 8), probably because the mussels act directly on the phytoplankton and immobilize a larger amount of nutrients in tissue and fecal material than is removed by harvest. The simulated effects of nutrient load reductions might be underestimated in the present study, however, since the simulation period was too short to capture seasonal and yearly lag times (Kemp et al. 2009) and to obtain a steady state between loadings and environmental effects. The load reduction scenarios are within the range of necessary reductions required to obtain good ecological status in Danish coastal waters (Erichsen et al. 2017), but it is unknown if and how nutrient reduction measures will be implemented. Although mitigation mussel cultures seem to be an efficient tool to reduce chl $a$ and improve light conditions on a basin scale, it should be noticed that the main environmental impact is within the farm, whereas nutrient reductions from land mainly affect areas closer to the coastline. Hence, land-based measures may be more beneficial for submerged rooted vegetation such as eelgrass, which is often located in coastal shallow areas. Model studies do, 
however, indicate that careful positioning of mussel farms can be used to increase water transparency at selected coastal (beach) sites (Schernewski et al. 2018), and the same principles might also be applied to improve growth conditions for eelgrass and other anchored vegetation. However, mussel production will have an immediate effect in the marine environment, unlike most land-based measures where there is a lag phase of several years between implementation and detectable effects (Hart 2003, Kemp et al. 2009). Further, mussel production and other marine extraction cultures can immobilize and remove nutrients released from the sediments, deposited from the atmosphere or coming from other marine areas. Although mussel farming can be performed in most eutrophied marine environments, the production is vulnerable towards environmental conditions such as storms, oxygen depletion events and predation. Technological innovation may reduce the risk of production failure due to environmental conditions, but the risk of production failure cannot be eliminated. In addition, mitigation mussel farms may lead to an increased level of conflict due to the occupation of space by the farms and the potential interference with other activities such as fishing and commercial and recreational sailing.

The basin-scale environmental impacts of mitigation cultures were addressed using a combination of field measurements and model simulations. Ecological models are constrained by the availability of data but are useful tools to evaluate complex physical and ecological interactions with high temporal and spatial resolution. The present model study allowed us to assess the ecological footprint of mitigation farms and extrapolate to basin-scale effects. The ecological model was parameterized and calibrated using monitoring data of salinity, temperature, nutrients, $\mathrm{chl} a$ concentration, mussel biomass and length of individual mussels.

Overall, the model was able to reproduce the variation in salinity mainly driven by differences between boundary salinities on the western and eastern boundaries resulting in a permanent horizontal salinity gradient and vertical mixing as well as the main seasonal pattern in temperature and the selected nutrients and chl a. For $\mathrm{NO}_{3}{ }^{-}$, the seasonal pattern was characterized by high winter concentrations and summer concentrations below detection limits, which are common for Danish estuaries (Kaas et al. 1996, Conley et al. 2000). Both observed and simulated concentrations of $\mathrm{PO}_{4}{ }^{3-}$ and $\mathrm{NH}_{4}{ }^{+}$were characterized by high summer and autumn concentrations caused by bottom water anoxia, which is occurring every year in Skive Fjord, resulting in changed redox potential and reduced nitrification and hence allowing for $\mathrm{PO}_{4}{ }^{3-}$ and $\mathrm{NH}_{4}{ }^{+}$to be released from the sediments at rates exceeding phytoplankton nutrient uptake rates. The ability of the model to capture this late summer peak in $\mathrm{PO}_{4}{ }^{3-}$ and $\mathrm{NH}_{4}{ }^{+}$suggests that the sediment part of the model provides an overall good description of the biogeochemical reactions and redox conditions in the sediment.

The seasonal chl a pattern in Skive Fjord is characterized by a high summer and autumn concentration following the release of nutrients from the sediments. This more bell-shaped chl a pattern is typical for highly eutrophic estuaries where nutrients are not a limiting factor. Although Limfjorden in general and Skive Fjord in particular are frequently stratified (Maar et al. 2010), neither observations nor model results revealed any nutrient or chl a depth gradients, indicating that the mixing of the water column is sufficient to prevent nutrient depletion in surface waters and phytoplankton depletion in bottom waters. The modelled spatial scale effects of the mussel farm on chl a concentration was confirmed by high-resolution towed sensor data showing chl a depletion not only within the farm but also in the surrounding water (Nielsen et al. 2016).

The modelled biomass and shell length of farmed blue mussels increased over time from the settling in June until November. During the winter, both biomass and shell length remained constant but increased at the end of the simulation period (May). This pattern was similar to the measurements from the experimental longline unit in Skive Fjord, although the increase in biomass at the end of the experiment (June 2011) appeared to be more pronounced than that predicted by the model. Model results indicated growth differences $(<10 \%$ from the mean) between the sections of the mitigation farm resulting from differences in growth conditions. However, this pattern was not confirmed by observations, which showed no significant difference in biomass between farm sections (Nielsen et al. 2016).

Model results indicating higher sedimentation within the farm relative to outside the farm were supported by comparable sedimentation measurements performed in the same period and location (Holmer et al. 2015). The model results further indicated that the increased farm-scale sedimentation was compensated by a decreased basin-scale sedimentation. This model result cannot be validated by comparison with data, however, as suitable data on basin-scale sedimentation rates do not exist and would require elab- 
orate studies. Hence, the modelling points to effects of mitigation cultures that are difficult to assess in situ. The combination of modelling and field observations proved to be a valuable tool for quantifying the short-term $(<1 \mathrm{yr})$ environmental effects of mitigation mussel cultures on a basin scale. For mitigation mussel production to be used to as a national management tool to improve water quality, more knowledge, especially on optimal site selection, nutrient removal and cost efficiency in different types of marine environments, is needed.

Acknowledgements. This study was part of the research project MuMiHus funded by the Danish Council for Strategic Research (grant agreement no. 09-066983), the MuMiPro project funded by Innovation Fund Denmark (grant agreement no. 6150-00008B) and the BONUS-Optimus project. We thank the MuMiHus research team for field data and valuable discussions.

\section{LITERATURE CITED}

Afrose S, Hammershøj M, Nørgaard JV, Engberg RM, Steenfeldt S (2016) Influence of blue mussel (Mytilus edulis) and starfish (Asterias rubens) meals on production performance, egg quality and apparent total tract digestibility of nutrients of laying hens. Anim Feed Sci Technol 213:108-117

Andersen HE, Kronvang B, Larsen SE (2005) Development, validation and application of Danish empirical phosphorus models. J Hydrol (Amst) 304:355-365

Anderson DM, Glibert PM, Burkholder JM (2002) Harmful algal blooms and eutrophication: nutrient sources, composition, and consequences. Estuaries 25:704-726

* Anton A, Cebrian J, Heck KL, Duarte CM, Sheehan KL, Miller ME, Foster D (2011) Decoupled effects (positive to negative) of nutrient enrichment on ecosystem services. Ecol Appl 21:991-1009

Bruggeman J, Bolding K (2014) A general framework for aquatic biogeochemical models. Environ Model Softw 61:249-265

* Burchard H, Bolding K, Villarreal MR (2004) Three-dimensional modelling of estuarine turbidity maxima in a tidal estuary. Ocean Dyn 54:250-265

Carlsson M, Holmer M, Petersen J (2009) Seasonal and spatial variations of benthic impacts of mussel longline farming in a eutrophic Danish fjord, Limfjorden. J Shellfish Res 28:791-801

Carlsson MS, Engström P, Lindahl O, Ljungqvist L, Petersen JK, Svanberg L, Holmer M (2012) Effects of mussel farms on the benthic nitrogen cycle on the Swedish west coast. Aquacult Environ Interact 2:177-191

Carpenter SR, Caraco NF, Correll DL, Howarth RW, Sharpley AN, Smith VH (1998) Nonpoint pollution of surface waters with phosphorus and nitrogen. Ecol Appl 8: $559-568$

Carstensen J, Henriksen P, Heiskanen AS (2007) Summer algal blooms in shallow estuaries: definition, mechanisms, and link to eutrophication. Limnol Oceanogr 52: 370-384
Christensen PB, Møhlenberg F, Krause-Jensen D, Rysgaard S and others (1994) Stoftransport og stofomsætning i Kertinge Nor/Kerteminde Fjord. Havforskning fra Miljøstyrelsen, bind 43. Danish Environmental Protection Agency, Copenhagen

Christensen PB, Rysgaard S, Sloth NP, Dalsgaard T, Schwærter S (2000) Sediment mineralization, nutrient fluxes, denitrification and dissimilatory nitrate reduction to ammonium in an estuarine fjord with sea cage trout farms. Aquat Microb Ecol 21:73-84

Christensen PB, Glud RN, Dalsgaard T, Gillespie P (2003) Impacts of longline mussel farming on oxygen and nitrogen dynamics and biological communities of coastal sediments. Aquaculture 218:567-588

Conley DJ, Kaas H, Mohlenberg F, Rasmussen B, Windolf J (2000) Characteristics of Danish estuaries. Estuaries 23: 820-837

* Cranford PJ, Strain PM, Dowd M, Hargrave BT, Grant J, Archambault MC (2007) Influence of mussel aquaculture on nitrogen dynamics in a nutrient enriched coastal embayment. Mar Ecol Prog Ser 347:61-78

* Diaz RJ, Rosenberg R (2008) Spreading dead zones and consequences for marine ecosystems. Science 321:926-929

Erichsen AC (ed) Timmermann K (ed), Christensen JPA, Kaas H, Markager S, Møhlenberg F (2017) Development of models and methods to support the Danish river basin management plans: scientific documentation. Department of Bioscience, Aarhus University and DHI, Roskilde

Gallardi D (2014) Effects of bivalve aquaculture on the environment and their possible mitigation: a review. Fish Aquac J 5:105

*Giles H, Pilditch CA, Bell DG (2006) Sedimentation from mussel (Perna canaliculus) culture in the Firth of Thames, New Zealand: impacts on sediment oxygen and nutrient fluxes. Aquaculture 261:125-140

Hart R (2003) Dynamic pollution control—time lags and optimal restoration of marine ecosystems. Ecol Econ 47: 79-93

*Hofmeister R, Burchard H, Bolding K (2009) A threedimensional model study on processes of stratification and de-stratification in the Limfjord. Cont Shelf Res 29: 1515-1524

*Holmer M, Thorsen SW, Carlsson MS, Kjerulf PJ (2015) Pelagic and benthic nutrient regeneration processes in mussel cultures (Mytilus edulis) in a eutrophic coastal area (Skive Fjord, Denmark). Estuaries Coasts 38: 1629-1641

*Humphries AT, Ayvazian SG, Carey JC, Hancock BT and others (2016) Directly measured denitrification reveals oyster aquaculture and restored oyster reefs remove nitrogen at comparable high rates. Front Mar Sci 3:74

Jørgensen BB, Richardson K (1996) Eutrophication in coastal marine ecosystems. American Geophysical Union, Washington, DC

Kaas H, Møhlenberg F, Josefson AB, Rasmussen B and others (1966) Marine områder. Danske fjorde-status over miljøtilstand, årsagssammenhænge og udvikling. Faglig rapport fra DMU nr. 179. Ministry of the Environment and Energy, National Environmental Research Institute, Roskilde

Kemp WM, Testa JM, Conley DJ, Gilbert D, Hagy JD (2009) Temporal responses of coastal hypoxia to nutrient loading and physical controls. Biogeosciences 6:2985-3008

*Kooijman SALM (1986) Energy budgets can explain body size relations. J Theor Biol 121:269-282 
Kooijman SALM (2010) Dynamic energy and mass budgets in biological systems. Cambridge University Press, Cambridge

Kronvang B, Andersen HE, Borgesen C, Dalgaard T, Larsen SE, Bogestrand J, Blicher-Mathiasen G (2008) Effects of policy measures implemented in Denmark on nitrogen pollution of the aquatic environment. Environ Sci Policy 11:144-152

* Lindahl O, Hart R, Hernroth B, Kollberg S and others (2005) Improving marine water quality by mussel farming: a profitable solution for Swedish society. Ambio 34:131-138

* Maar M, Bolding K, Petersen JK, Hansen JLS, Timmermann K (2009) Local effects of blue mussels around turbine foundations in an ecosystem model of Nysted off-shore wind farm, Denmark. J Sea Res 62: 159-174

* Maar M, Timmermann K, Petersen JK, Gustafsson KE, Storm LM (2010) A model study of the regulation of blue mussels by nutrient loadings and water column stability in a shallow estuary, the Limfjorden. J Sea Res 64: 322-333

Maar M, Markager S, Madsen KS, Windolf J, Lyngsgaard MM, Andersen HE, Moller EF (2016) The importance of local versus external nutrient loads for chl $a$ and primary production in the western Baltic Sea. Ecol Modell 320: 258-272

Markager S, Stedmon CA, Sondergaard M (2011) Seasonal dynamics and conservative mixing of dissolved organic matter in the temperate eutrophic estuary Horsens Fjord. Estuar Coast Shelf Sci 92:376-388

McKindsey CW, Archambault P, Callier MD, Olivier F (2011) Influence of suspended and off-bottom mussel culture on the sea bottom and benthic habitats: a review. Can J Zool 89:622-646

Mohlenberg F (1999) Effect of meteorology and nutrient load on oxygen depletion in a Danish micro-tidal estuary. Aquat Ecol 33:55-64

Nielsen SL, Sand-Jensen K, Borum J, Geertz-Hansen O (2002) Depth colonization of eelgrass (Zostera marina) and macroalgae as determined by water transparency in Danish coastal waters. Estuaries 25:1025-1032

Nielsen P, Cranford PJ, Maar M, Petersen JK (2016) Magnitude, spatial scale and optimization of ecosystem services from a nutrient extraction mussel farm in the eutrophic Skive Fjord, Denmark. Aquacult Environ Interact 8:311-329

Nizzoli D, Welsh DT, Fano EA, Viaroli P (2006) Impact of clam and mussel farming on benthic metabolism and nitrogen cycling, with emphasis on nitrate reduction pathways. Mar Ecol Prog Ser 315:151-165

* Nørgaard JV, Petersen JK, Tørring DB, Jørgensen H, Lærke HN (2015) Chemical composition and standardized ileal digestibility of protein and amino acids from blue mussel, starfish, and fish silage in pigs. Anim Feed Sci Technol 205:90-97

* Petersen JK, Bougrier S, Smaal AC, Garen P, Robert S, Larsen JEN, Brummelhuis E (2004) Intercalibration of mussel Mytilus edulis clearance rate measurements. Mar Ecol Prog Ser 267:187-194

Petersen JK, Hansen JW, Laursen MB, Clausen P, Carstensen J, Conley DJ (2008) Regime shift in a coastal marine ecosystem. Ecol Appl 18:497-510

Petersen JK, Timmermann K, Carlsson M, Holmer M, Maar M, Lindahl O (2012) Mussel farming can be used as a mitigation tool—a reply. Mar Pollut Bull 64:452-454
Petersen JK, Hasler B, Timmermann K, Nielsen P, Tørring DB, Larsen MM, Holmer M (2014) Mussels as a tool for mitigation of nutrients in the marine environment. Mar Pollut Bull 82:137-143

* Petersen JK, Saurel C, Nielsen P, Timmermann K (2016) The use of shellfish for eutrophication control. Aquacult Int 24:857-878

Petersen JK, Holmer M, Termansen M, Hasler B (2019) Nutrient extraction through bivalves. In: Smaal AC, Ferreira JG, Grant J, Petersen JK, Strand Ø (eds) Goods and services of marine bivalves. Springer, Cham, p 179-208

* Pouvreau S, Bourles Y, Lefebvre S, Gangnery A, AlunnoBruscia M (2006) Application of a dynamic energy budget model to the Pacific oyster, Crassostrea gigas, reared under various environmental conditions. J Sea Res 56:156-167

* Riemann B, Carstensen J, Dahl K, Fossing H and others (2016) Recovery of Danish coastal ecosystems after reductions in nutrient loading: a holistic ecosystem approach. Estuaries Coasts 39:82-97

Kiisgård HU (2001) On measurement of filtration rates in bivalves - the stony road to reliable data: review and interpretation. Mar Ecol Prog Ser 211:275-291

* Schröder T, Stank J, Schernewski G, Krost P (2014) The impact of a mussel farm on water transparency in the Kiel Fjord. Ocean Coast Manage 101:42-52

* Schernewski G, Friedland R, Buer AL, Dalke S and others (2018) Ecological-social-economic assessment of zebramussel cultivation scenarios for the Oder (Szczecin) Lagoon. J Coast Conserv, doi:10.1007/s11852-018-0649-2

Stadmark J, Conley DJ (2011) Mussel farming as a nutrient reduction measure in the Baltic Sea: consideration of nutrient biogeochemical cycles. Mar Pollut Bull 62: 1385-1388

* Strohmeier T, Aure J, Duinker A, Castberg T, Svardal A, Strand $\varnothing$ (2005) Flow reduction, seston depletion, meat content and distribution of diarrhetic shellfish toxins in a long-line blue mussel (Mytilus edulis) farm. J Shellfish Res 24:15-23

*Testa JM, Brady DC, Cornwell JC, Owens MS and others (2015) Modeling the impact of floating oyster (Crassostrea virginica) aquaculture on sediment-water nutrient and oxygen fluxes. Aquacult Environ Interact 7: 205-222

Tett P (1998) Parameterising a microplankton model. Napier University, Edinburgh

* Timmermann K, Markager S, Gustafsson KE (2010) Streams or open sea? Tracing sources and effects of nutrient loadings in a shallow estuary with a 3D hydrodynamicecological model. J Mar Syst 82:111-121

*Van Haren RJF, Kooijman SALM (1993) Application of a dynamic energy budget model to Mytilus edulis. Neth J Sea Res 31:119-133

Windolf J, Thodsen H, Troldborg L, Larsen SE, Bogestrand J, Ovesen NB, Kronvang B (2011) A distributed modelling system for simulation of monthly runoff and nitrogen sources, loads and sinks for ungauged catchments in Denmark. J Environ Monit 13:2645-2658

Windolf J, Timmermann A, Kjeldgaard A, Bøgestrand J, Larsen SE, Thodsen H (2103) Landbaseret tilførsel af kvælstof og fosfor til Danske fjorde og kystafsnit, 1990-2011. Teknisk rapport fra DCE-Nationalt Center for Miljø og Energi nr. 31. Department of Bioscience, Aarhus University

Submitted: April 9, 2018; Accepted: February 18, 2019

Proofs received from author(s): April 25, 2019 